\title{
Evaluation of Techniques That Measure Hydrogen and Methane Levels in Breaths of Horses with Gastrointestinal Diseases
}

\author{
Naoki SASAKI $^{1 *}$, Morito FUKUNAKA ${ }^{1}$, Haruo YAMADA ${ }^{1}$, Hiroyuki SENBA ${ }^{2}$ and \\ Tohru HIGUCHI ${ }^{3}$ \\ ${ }^{1}$ Department of Veterinary Surgery, Obihiro University of Agriculture \& Veterinary Medicine, Inada-town, \\ Obihiro-city, Hokkaido 080-8555, ${ }^{2}$ Kyushu Stallion Station, Japan Bloodhorse Breeders Association, Nagata \\ 3995, Osaki-town, Kagoshima 899-8313, ${ }^{3}$ Animal Clinic Center, Agricultural Mutual Relief Association, \\ Higashihorai 200, Mitsuishi, Hokkaido 059-3105, Japan
}

Techniques for measuring hydrogen $\left(\mathrm{H}_{2}\right)$ and methane $\left(\mathrm{CH}_{4}\right)$ levels in breaths were assessed in horses with gastrointestinal (GI) diseases. A total of 31 horses were studied: 11 healthy horses (Group A), 10 horses with GI diseases (Group B), and 10 horses with diseases without GI involvement (Group C). Expired gases were measured using gas chromatography. $\mathrm{CH}_{4}$ levels in Group A were significantly lower than those in Group B. In Group B, $\mathrm{CH}_{4}$ levels were significantly higher after treatment. Fluctuations in $\mathrm{H}_{2}$ and $\mathrm{CH}_{4}$ levels in breath were associated with changes in GI function.

Key words: equine, hydrogen, methane
J. Equine Sci.

Vol. 17, No. 2

pp. 39-43, 2006
In horses, gastrointestinal (GI) diseases such as colic occur frequently and are often life-threatening. Various GI diseases accompany GI dysfunction, which leads to bacterial abnormality in the GI tract [2]. Bacterial overgrowth accompanying acute abdominal conditions, especially ileus, has been previously reported [2]. Currently, GI diseases in horses are primarily diagnosed by external observation, auscultation, rectal palpation, endoscopy, and ultrasound. However, objective diagnostic techniques have not been adequately developed, since horses have enormous GI tracts. Although the evaluation of changes in bacterial flora appears to be an effective and objective diagnostic strategy for GI diseases, as a practical matter, it is difficult to culture and identify numerous enteric bacteria. In humans, hydrogen $\left(\mathrm{H}_{2}\right)$ and methane $\left(\mathrm{CH}_{4}\right)$ produced by enteric bacteria are absorbed into the GI tract, delivered into circulation, and eventually, expired by the lungs following gas exchange $[12,13]$. This flow is utilized clinically for testing carbohydrate malabsorption $[1,3,14]$ and

This article was accepted February 17, 2006

*Corresponding author. e-mail: naoki@obihiro.ac.jp testing $\mathrm{H}_{2}$ and $\mathrm{CH}_{4}$ levels in the breath to measure their transit time in the GI tract $[8,16]$. Results from these tests have indicated high concentrations of $\mathrm{H}_{2}$ and $\mathrm{CH}_{4}$ in the breath of humans with GI diseases [14]. A report has also been made on a similar technique applied to horses, which demonstrated the ease of use and reproducibility of measuring $\mathrm{H}_{2}$ and $\mathrm{CH}_{4}$ levels in the breath [18]. This breath technique revealed a decrease in $\mathrm{H}_{2}$ production following administration of antimicrobial agents, which resulted in changes in bacterial flora and diarrhea [19]. Thus, we hypothesized that intestinal fermentation associated with bacterial overgrowth and GI diseases, such as digestion and absorption disorder and GI motility disorder, may be diagnosed by assessing changes in gas production in the GI tract. In this study, we measured $\mathrm{H}_{2}$ and $\mathrm{CH}_{4}$ levels in the breath of horses with various GI diseases. We then determined from the results whether this technique can be used as an objective diagnosis for equine GI diseases.

A total of 31 horses allocated to three groups were studied. Group A consisted of 11 healthy thoroughbred horses ( 1 male, 1 female, 8 castrated males, mean age: $11.0 \pm 3.8$ years [mean $\pm \mathrm{SD}]$ ), Group $\mathrm{B}$ consisted of 10 thoroughbred horses that visited the 
Table 1. Comparison of $\mathrm{H}_{2}$ and $\mathrm{CH}_{4}$ levels in breath of Group A horses

\begin{tabular}{ccclcc}
\hline No & sex & age & disease & $\mathrm{H}_{2}(\mathrm{ppm})$ & $\mathrm{CH}_{4}(\mathrm{ppm})$ \\
\hline 1 & gelding & 7 & healthy & 3.6 & 319.5 \\
2 & gelding & 7 & healthy & 1.8 & 200.8 \\
3 & gelding & 15 & healthy & 1.9 & 249.1 \\
4 & gelding & 12 & healthy & 2.6 & 225.4 \\
5 & gelding & 13 & healthy & 12.5 & 406.1 \\
6 & gelding & 16 & healthy & 1.7 & 169.3 \\
7 & gelding & 8 & healthy & 3.0 & 94.2 \\
8 & mare & 12 & healthy & 2.9 & 202.6 \\
9 & gelding & 16 & healthy & 2.9 & 134.8 \\
10 & gelding & 9 & healthy & 0.8 & 177.8 \\
11 & stallion & 6 & healthy & 1.9 & 133.6 \\
\hline \multirow{2}{*}{ mean } & \pm SD & $11 \pm 3.8$ & & $3.2 \pm 3.2$ & $210.3 \pm 89.4$ \\
\hline
\end{tabular}

Table 2. Comparison of $\mathrm{H}_{2}$ and $\mathrm{CH}_{4}$ levels in breath of Group B horses

\begin{tabular}{lcrccc}
\hline No & sex & age & disease & $\mathrm{H}_{2}(\mathrm{ppm})$ & $\mathrm{CH}_{4}(\mathrm{ppm})$ \\
\hline 1 & stallion & 0 & colic & 8.3 & 34.4 \\
2 & mare & 12 & large colon volvulus & 5.6 & 47.5 \\
3 & mare & 13 & large colon volvulus & 6.5 & 89.9 \\
4 & mare & 6 & large colon volvulus & 4.6 & 105.9 \\
5 & stallion & 2 & impaction & 0 & 59.6 \\
6 & mare & 6 & large colon volvulus & 20.1 & 69.7 \\
7 & mare & 12 & impaction & 1.0 & 93.7 \\
8 & stallion & 0 & colic & 35.8 & 97.5 \\
9 & mare & 3 & impaction & 0 & 90.6 \\
10 & stallion & 0 & umbilical hernia & 6.0 & 49.4 \\
\hline \multirow{2}{*}{ mean \pm SD } & $5.4 \pm 5.3$ & & $8.8 \pm 11.1$ & $73.8 \pm 24.9$ \\
\hline
\end{tabular}

Table 3. Comparison of $\mathrm{H}_{2}$ and $\mathrm{CH}_{4}$ levels in breath of Group $\mathrm{C}$ horses

\begin{tabular}{cccccc}
\hline No & sex & age & disease & $\mathrm{H}_{2}(\mathrm{ppm})$ & $\mathrm{CH}_{4}(\mathrm{ppm})$ \\
\hline 1 & mare & 1 & fracture & 2.0 & 139.8 \\
2 & stallion & 0 & fracture & 7.6 & 68.5 \\
3 & mare & 2 & fracture & 2.4 & 90.2 \\
4 & stallion & 2 & fracture & 41.4 & 138.3 \\
5 & stallion & 3 & fracture & 5.3 & 207.8 \\
6 & stallion & 1 & limb deformities & 13.3 & 276.9 \\
7 & stallion & 1 & osteochondrosis & 0.6 & 77.8 \\
8 & stallion & 1 & osteochondrosis & 6.2 & 153.8 \\
9 & mare & 6 & corneal ulcer & 3.3 & 43 \\
10 & stallion & 1 & osteochondrosis & 0.1 & 39.3 \\
\hline \multirow{2}{*}{ mean \pm SD } & $1.8 \pm 1.7$ & & $8.2 \pm 11.7$ & $123.5 \pm 72.0$
\end{tabular}

Animal Medical Center, Hidaka Agricultural Cooperative Association with GI diseases (4 male, 6 female, mean age: $5.4 \pm 5.3$ years), and Group C consisted of 10 thoroughbred horses that visited the Animal Medical Center with non-GI diseases ( 7 male, 3 female, mean age: $1.8 \pm 1.7$ years).

Tables 1, 2, and 3 show the health conditions of horses in Groups A, B, and C, respectively. Horses in Group B received laparotomy for colonic volvulus, colic, or umbilical hernia. Xylazine $(1.0 \mathrm{mg} / \mathrm{kg})$, ketamin $(2.5 \mathrm{mg} / \mathrm{kg})$, and midazolam $(0.05 \mathrm{mg} / \mathrm{kg})$ were administered intravenously and the horses were laid on their sides. Anesthesia was maintained by isoflurane in oxygen for $134.0 \pm 10.8 \mathrm{~min}(\mathrm{n}=5$, mean \pm $\mathrm{SD})$. In Group C, horses that underwent surgery for bone fracture, ridgling, or osteochondropathy received the same anesthetic procedure as in Group B, and the duration of anesthesia was $91.7 \pm 51.3 \mathrm{~min}(\mathrm{n}=6$, mean \pm SD). Those that underwent operation for umbilical hernia, crabfoot, elbow tumor, or keratitis received xylazine $(1.0 \mathrm{mg} / \mathrm{kg})$, ketamin $(2.5 \mathrm{mg} / \mathrm{kg})$, and midazolam $(0.05 \mathrm{mg} / \mathrm{kg})$ and were laid on their sides. Their anesthesia was maintained by triple-drip infusion (500 $\mathrm{ml}$ of $5 \%$ glucose solution containing $250 \mathrm{mg}$ xylazine, 1,000 mg ketamine, and $25 \mathrm{~g}$ guaifenesin).

Breath samples were collected using the closed circuit rebreathing technique under consciousness. Horses wore an air-tight face mask for $30 \mathrm{sec}$. Expired breaths were collected into an aluminum bag containing $10 l$ of pure oxygen (AA-10, GL Sciences, Tokyo).

Following the collection of expired breaths $2 \mathrm{ml}$ of the air from the bag was analyzed by portable gas chromatography $\left(\mathrm{H}_{2}-\mathrm{CO}-\mathrm{CH}_{4}\right.$ Analyzer HCMA-T1, Abilit, Japan) in order to measure expired $\mathrm{H}_{2}$ and $\mathrm{CH}_{4}$ concentration levels. This procedure was repeated twice, and the mean values were used for analysis.

$\mathrm{H}_{2}$ and $\mathrm{CH}_{4}$ levels in breaths were compared between Groups A $(n=11)$ and B $(n=10)$. For Group B, $\mathrm{H}_{2}$ and $\mathrm{CH}_{4}$ levels in breaths before the treatment were compared with those after the treatment in which the symptom was improved. Additionally, for the 4 horses with colonic volvulus that underwent laparotomy and the pelvic flexure incision, $\mathrm{H}_{2}$ and $\mathrm{CH}_{4}$ levels were measured preoperatively, $15 \mathrm{hr}$ postoperatively, and 10 days postoperatively. For Group $\mathrm{C}(\mathrm{n}=10), \mathrm{H}_{2}$ and $\mathrm{CH}_{4}$ levels obtained before using systemic anesthesia and immediately after recovery from anesthesia were compared.

All results from the tests were expressed as mean \pm SD. To evaluate the significance in $\mathrm{H}_{2}$ and $\mathrm{CH}_{4}$ levels between Groups A and B, the Mann-Whitney U test and Welch's $t$-test were used, respectively. The Wilcoxon 


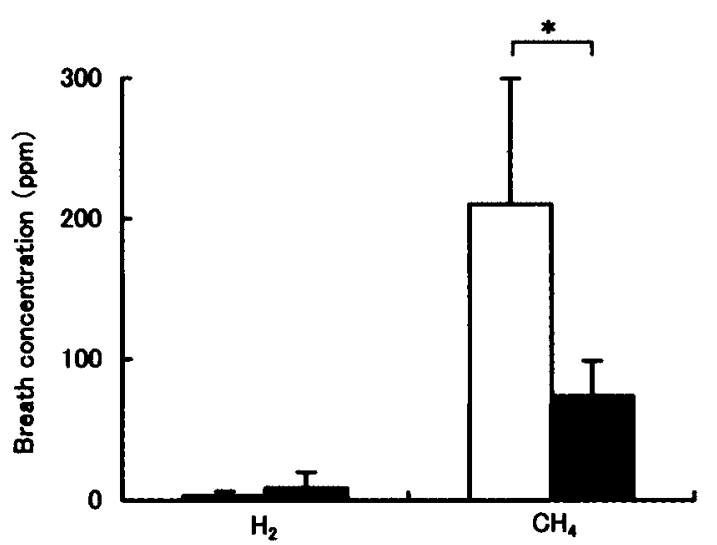

Fig. 1. Comparison of $\mathrm{H}_{2}$ and $\mathrm{CH}_{4}$ levels in breath of healthy horses and horses with GI diseases. $\square$ : Group A (healthy horses, $\mathrm{n}=11$ ), $\mathbf{0}$ : Group B (horses with GI diseases, $\mathrm{n}=10)$. Values are mean $\pm \mathrm{SD} .{ }^{* *}: \mathrm{p}<0.01$.

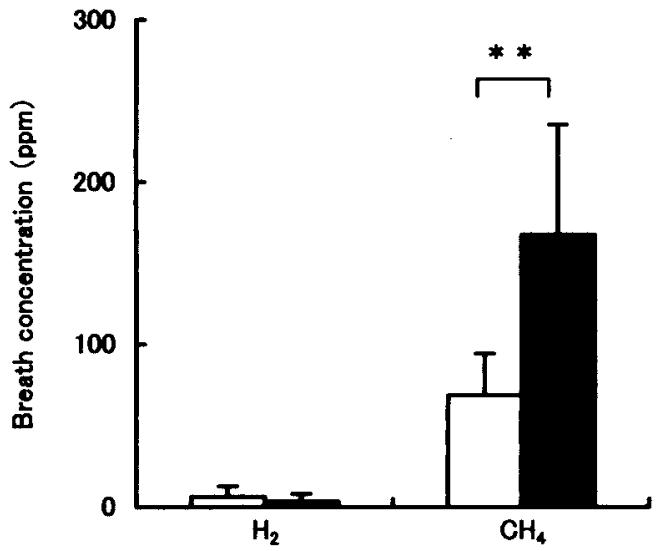

Fig. 2. Changes in $\mathrm{H}_{2}$ and $\mathrm{CH}_{4}$ levels in breath before and after treatment in horses with GI diseases. $\square$ : Before treatment $(\mathrm{n}=8), \boldsymbol{\square}$ : After treatment $(\mathrm{n}=8)$. Values are mean $\pm \mathrm{SD}$. **: $\mathrm{p}<0.01$.
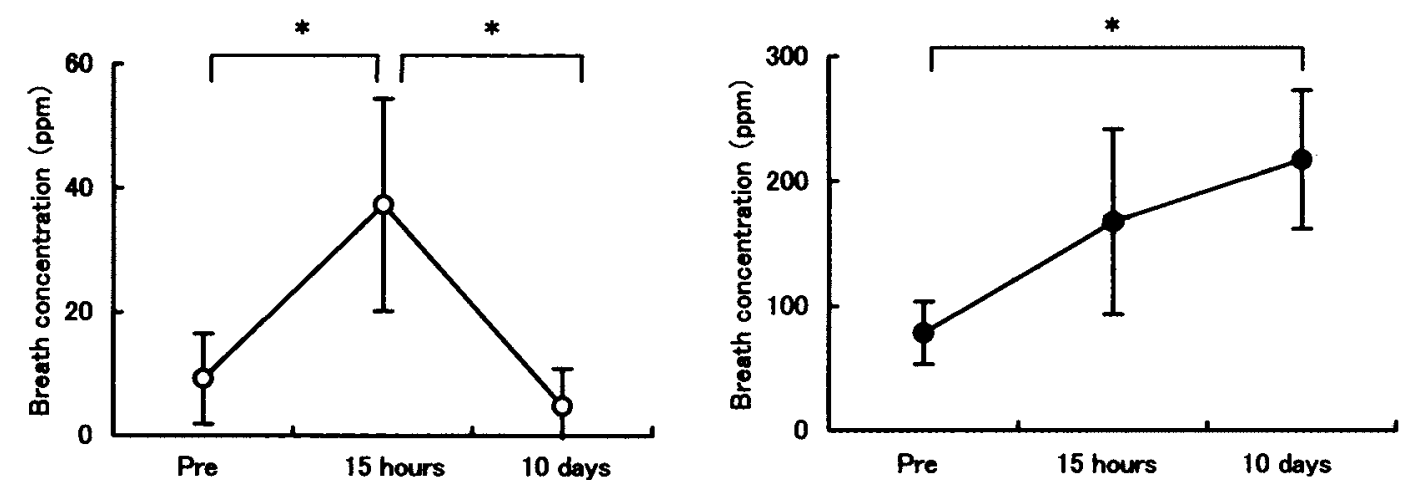

Fig. 3. Changes in gas levels in breath of horses with colonic volvulus. (a) $\mathrm{H}_{2}$ levels in breath, (b) $\mathrm{CH}_{4}$ levels in breath. $\bigcirc: \mathrm{H}_{2}$ levels in breath $(\mathrm{n}=4)$,

$\mathrm{CH}_{4}$ levels in breaths $(\mathrm{n}=4)$. Values are mean $\pm \mathrm{SD}$. *: $\mathrm{p}<0.05$.

test was used for $\mathrm{H}_{2}$ levels measured before and after treatment in Group B and before and after anesthesia in Group C, and the paired $t$-test was used for $\mathrm{CH}_{4}$ levels. For fluctuations of gas levels in breaths of horses with colonic volvulus, overall significance was analyzed using one-way ANOVA. If significance was found, a multiple comparison test (Scheffe's F-test) was used to verify the significance. Statistical significance was determined by a $\mathrm{p}$ value less than 0.05 .

Figure 1 shows $\mathrm{H}_{2}$ and $\mathrm{CH}_{4}$ levels in breaths for Groups A and B. $\mathrm{CH}_{4}$ levels in Group B (73.8 \pm 24.9 ppm) were significantly lower than those in Group A $(210.3 \pm 89.4 \mathrm{ppm})(\mathrm{p}<0.01) . \mathrm{H}_{2}$ levels in Group B (8.8 $\pm 11.1 \mathrm{ppm}$ ) tended to be higher than those in Group A (3.2 $\pm 3.2 \mathrm{ppm})$, but no significant difference was found. Changes of $\mathrm{H}_{2}$ and $\mathrm{CH}_{4}$ levels before and after treatment in Group B are shown in Fig. 2. Compared to the level before treatment, the $\mathrm{CH}_{4}$ level was significantly increased after treatment (167.6 \pm 67.9 ppm, $\mathrm{p}<0.01)$. The $\mathrm{H}_{2}$ level decreased with a minor extent after treatment $(\mathrm{p}>0.05)$. Changes in $\mathrm{H}_{2}$ and $\mathrm{CH}_{4}$ levels in breaths of Group B horses with colonic volvulus are shown in Fig. 3. At $15 \mathrm{hr}$ after operation, $\mathrm{H}_{2}$ levels $(37.3 \pm 17.1 \mathrm{ppm})$ had significantly increased compared to preoperative levels $(\mathrm{p}<0.05)$. At 10 days following surgery, $\mathrm{H}_{2}$ levels $(4.8 \pm 6.1 \mathrm{ppm})$ had significantly decreased compared to the levels at $15 \mathrm{hr}$ post operation $(\mathrm{p}<0.05)$, indicating that the concentration had returned to the normal range (Fig. 3a). $\mathrm{CH}_{4}$ levels measured at $15 \mathrm{hr}$ postoperatively 

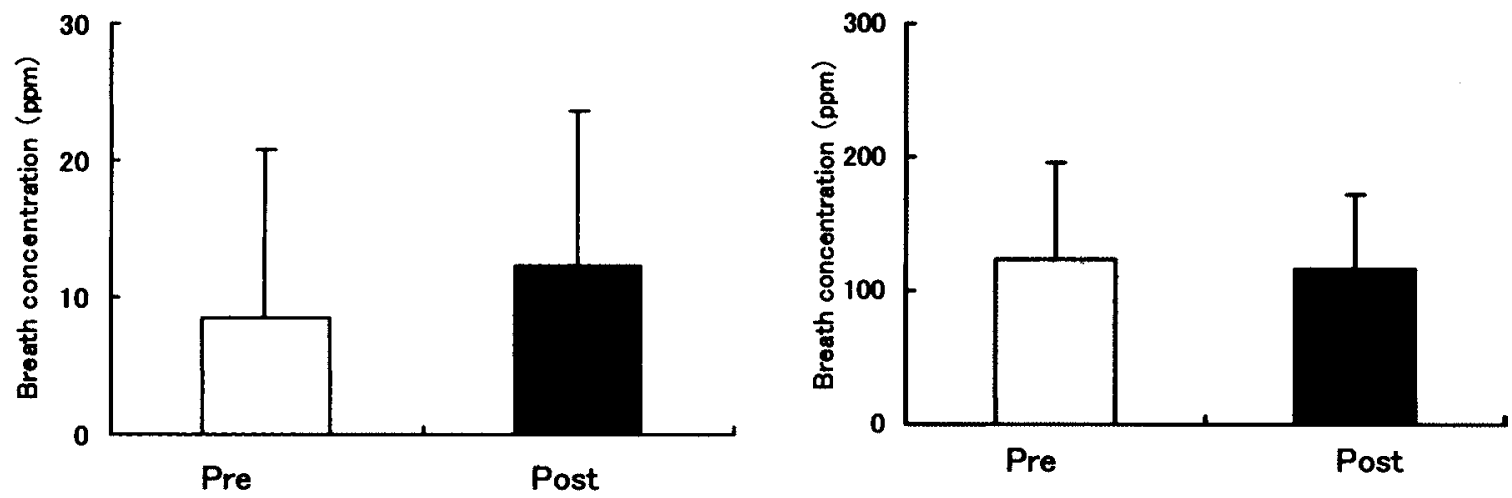

Fig. 4. Changes in gas levels in breath of horses without GI diseases before and after anesthesia. (a) $\mathrm{H}_{2}$ levels in breath ( $\mathrm{n}=9$ ), (b) $\mathrm{CH}_{4}$ levels in breath $(\mathrm{n}=10)$. $\square$ : Before anesthesia,

After anesthesia. Values are mean \pm SD

$(167.4 \pm 74.3 \mathrm{ppm})$ tended to be greater than those measured preoperatively $(78.3 \pm 25.3 \mathrm{ppm})$. $\mathrm{CH}_{4}$ levels were significantly increased at 10 days post-operation $(217.2 \pm 55.6 \mathrm{ppm}, \mathrm{p}<0.05)$ (Fig. 3b). Figure 4 shows changes of $\mathrm{H}_{2}$ and $\mathrm{CH}_{4}$ levels in Group $\mathrm{C}$ breaths before and after systemic anesthesia. Compared to the levels before anesthesia $(8.4 \pm 13.0 \mathrm{ppm})$, H2 levels were slightly increased after anesthesia (12.3 \pm 12.1 ppm), but significance was not found. $\mathrm{CH}_{4}$ levels were barely changed before and after anesthesia.

The present study demonstrates that GI diseases in horses are associated with a significant decrease in $\mathrm{CH}_{4}$ levels in the breath. Since $\mathrm{H}_{2}$ and $\mathrm{CH}_{4}$ produced by enteric bacteria are absorbed by the GI tract, delivered into circulation, and expired by the lungs following gas exchange $[12,13]$, the decrease in $\mathrm{CH}_{4}$ in the breath is thought to be associated with a decrease in gas production or malabsorption by the GI mucus. Acute abdominal conditions, including ileus, accompany bacterial overgrowth due to abnormal GI motility [2], and as a result, gases, such as $\mathrm{H}_{2}$ and $\mathrm{CH}_{4}$, increase. In humans, an increase in $\mathrm{H}_{2}$ and $\mathrm{CH}_{4}$ levels in the breath has been reported in association with various GI diseases [15]. These reports suggest that gases produced by enteric bacteria increase in the diseased horse GI tract, rather than decrease. The amount of gas that can dissolve into circulation from the GI tract is limited [17]. Thus, GI tract disorders, such as ileus, can cause stagnation of gases and contents as well as dilation of the GI tract. The resulting increase in pressure in the GI tract may impair circulation and cause ischemia in the GI tract [5,9]. Therefore, the decrease in gas levels in breaths that was observed in horses with GI diseases in this study may have been due to impairment of circulation.

In general, blood $\mathrm{H}_{2}$ levels in humans are known to increase during sleep and $\mathrm{H}_{2}$ levels in breaths increase upon awaking, because the respiration rate is decreased during sleep [10]. However, in our study, no significant changes were observed in $\mathrm{H}_{2}$ and $\mathrm{CH}_{4}$ levels in breaths before and after anesthesia. Respiration was controlled appropriately under anesthesia, and this was probably why $\mathrm{H}_{2}$ and $\mathrm{CH}_{4}$ levels in breaths were only negligibly affected.

In horses with colonic volvulus, increases in $\mathrm{H}_{2}$ and $\mathrm{CH}_{4}$ levels were observed $15 \mathrm{hr}$ after operation. Since $\mathrm{H}_{2}$ and $\mathrm{CH}_{4}$ levels were barely affected by anesthesia, the changes in $\mathrm{H}_{2}$ and $\mathrm{CH}_{4}$ levels observed postoperatively was thought to have been associated with the surgical procedures. Circulatory impairment in the GI tract is usually accompanied by colonic volvulus [4, $6,7,11,15]$. Thus, it was inferred that the increase in $\mathrm{CH}_{4}$ which had levels in the breath observed $15 \mathrm{hr}$ postoperation and the transient increase in $\mathrm{H}_{2}$ levels in breaths were caused by $\mathrm{H}_{2}$ and $\mathrm{CH}_{4}$ stagnated in the GI tract, and gradually exited into breath as the circulation improved following surgery. At 10 days following surgery, $\mathrm{H}_{2}$ levels in the breath had decreased again, while $\mathrm{CH}_{4}$ levels had increased and reached the normal range. These changes were thought to be associated with an increase in $\mathrm{CH}_{4}$ levels in breath following improvement in circulation in the GI tract and the consumption of $\mathrm{H}_{2}$ by methane-producing bacteria in the GI tract [12].

Our study shows that $\mathrm{H}_{2}$ and $\mathrm{CH}_{4}$ levels in the breath fluctuate due to GI tract dysfunction. It also demonstrates that decreases in $\mathrm{H}_{2}$ and $\mathrm{CH}_{4}$ levels in the breath could be an effective diagnostic indicator of GI 
tract function and circulation. Accordingly, testing of $\mathrm{H}_{2}$ and $\mathrm{CH}_{4}$ levels in the breath is a promising diagnostic technique for evaluating GI health in horses.

\section{References}

1. Bahall, K.M., Scholfield, D.J., Sluijs, A.M., and Hallfrisch, J. 1998. Breath hydrogen and methane expiration in men and women after oat extract consumption. J. Nutr. 128: 79-84.

2. Clark, L.L. 1990. Feeding and digestive problem in horses. pp. 433-450. In: Veterinary Clinics of North America: Equine Practice, Saunders, Philadelphia.

3. Eastwood, M.A., and Allgood, G.S. 1995. The effect of olestra on breath gas production and faecal microbial counts. Eur. J. Clin. Nutr. 49: 627639.

4. Gibson, K.T., and Steel, C.M. 1999. Strangulating obstructions of the large colon in mature horses. Equine Vet. Educ. 11: 234-242.

5. Hanson, K. M. 1973. Hemodynamic effects of distension of the dog small intestine. Am. J. Physiol. 225: 456-460.

6. Harrison, I.W. 1988. Equine large intestinal volvulus: A review of 124 cases. Vet. Surg. 17: 77-81.

7. Hoogmoed, L.V., Snyder, J.R., Pascoe, J.R., and Olander, H. 2000. Use of pelvic flexure biopsies to predict survival after large colon torsion in horses. Vet. Surg. 29: 572-577.

8. Jorge, J.M.N., Wexner, S.D., and Ehrenpreis, E.D. 1994. The lactulose hydrogen breath test as a measure of orocaecal transit time. Eur. J. Surg. 160: 409-416.

9. Kachelhoffer, J., Pousee, A., Marascaux, J., Hurizaga, M., and Grenier, J.F. 1978. Effects of motility and luminal distention on dog small intestine hemodynamics. Eur. Surg. Res. 10: 184193.

10. Kagaya, M., Iwata, M., Toda, Y., Nakae, Y., and
Kondo, T. 1998. Circadian rhythm of breath hydrogen in young women. J. Gastroenterol. 33: 472-476.

11. Kawcak, C.E., Baxter, G.M., Getzy, D.M., Stashak, T.S. and Chapman, P.L. 1995. Abnormalities in oxygenation, coagulation, and fibrinolysis in colonic blood of horses with experimentally induced strangulation obstruction. Am. J. Vet. Res. 56: 1642-1650.

12. Mckay, L.F., Holbrook, W.P., and Eastwood, M.A. 1982. Methan and hydrogen production by human intestinal anaerobic bacteria. Acta pathol. Microbial. Immunol. Scand. Sect. 90: 257-260.

13. Michael, A., and Levitt, M.D. 1969. Production and excretion of hydrogen gas in man. Engl. J. Med. 281: 122-127.

14. Minocha, A., and Rashild, S. 1997. Reliability and reproducibility of breath hydrogen and methane in male diabetic subjects. Dig. Dis. Sci. 42: 672-676.

15. Moore, R.M., Hance, S.R., Hardy, J., Moore, B. R., Embertson, R.M., and Constable, P.D. 1996. Colonic luminal pressure in horses with strangulating and nonstrangulating obstruction of the large colon. Vet. Surg. 25: 134-141.

16. Oufir, L.E., Flourie, B., Varannes, S.B., Barry, J.L., Cloarec, D., Bornet, F., and Galmiche, J.P. 1996. Relations between transit time, fermentation products, and hydrogen-consuming flora in healthy humans. Gut. 38: 870-877.

17. Parks, D.A., and Jacobson, E.D. 1987. Mesenteric circulation. pp. 1649-1670. In: Physiology of the Gastrointestinal Tract, second edition, Raven Press, New York.

18. Sasaki, N., Hobo, S., and Yoshihara, T. 1999. Measurement for breath concentration of hydrogen and methane in horses. J. Vet. Med. Sci. 61: 1059-1062.

19. Solomons, N.W. 1981. Diagnosis and screening techniques for lactose maldigestion. pp. 91-109. In: Lactose Digestion. Baltimore and London. 